\title{
HUBUNGAN KARAKTERISTIK, POLA KONSUMSI GARAM DAN POLA MAKAN DENGAN KADAR EKSKRESI IODIUM URIN (EIU) PADA IBU HAMIL DI JEPARA, JAWA TENGAH
}

\author{
Teddy Wahyu Nugroho', Aras Utami', Ani Margawati* \\ ${ }^{1}$ Departemen Kedokteran Umum, Fakultas Kedokteran, Universitas Diponegoro, J1. Prof Sudarto, S.H, Tembalang, Jawa Tengah, 50275, Indonesia \\ ${ }^{2}$ Departemen Ilmu Gizi, Fakultas Kedokteran, Universitas Diponegoro, Jl. Prof. Sudarto SH, Tembalang, Semarang, Jawa Tengah 50275, Indonesia \\ *Korespondensi : animargawati@gmail.com
}

\begin{abstract}
Background: Iodine Deficiency Disorders (IDD) is a disorder that arises due to lack of iodine intake. IDD problems in Indonesia are quite a lot. Therefore, it is important to socialize adequate iodine intake to reduce the risk of IDD in the community. Groups that need socialization are women of childbearing age and pregnant women.

Objectives: To examine the relationship between urinary excretion of iodine (UEI) level with mid-upper arm circumference (MUAC), body mass index (BMI), anemia status, iodine consumption, and diet.

Methods: This study was an observational study conducted with a case-control study design. The subjects in this study were pregnant women in the 2 nd and $3 r d$ trimesters. The total sample of 88 pregnant women was a consecutive sampling. The research instruments were questionnaires, interviews related to food intake and iodized salt intake (SQ$F F Q$ ), and urine bottles to place the subject's urine before being tested by the Enzyme-Linked Immunosorbent Assay (ELISA) method. Data analysis was carried out by using descriptive analysis of subjects by presenting the frequency distribution of each variable. Bivariate analysis was used to determine the odds ratio of exposure to cases using a $2 \times 2$ table.

Results: Pregnant women in this study were 88 subjects. A total of $68.2 \%$ subjects had low UEI levels. In addition, of the total subjects, 46 subjects had nutritional status overweight (52.3\%) and 19 subjects (21.6\%) had anemia. The statistical test results showed that there was no correlation between MUAC $(p=0.843)$, nutritional status $(p=0.282)$, anemia status $(p=0.561)$, energy intake $(p=0.360)$, carbohidrat intake $(p=0.856)$, protein intake $(p=0.744)$, fat intake $(p=0.781)$, fiber intake $(p=.492)$; vitamin $C$ intake ( $p=0.401)$; magnesium intake $(p=0.177)$; iron intake/Fe $(p=0.122)$, zinc intake $(p=0.141)$, mangan intake $(p=0.286)$ with UEI levels in pregnant women.
\end{abstract}

Conclusion: There is no relationship between risk factors and dietary intake with UEI levels in pregnant women.

Keywords: Iodin; Dietary Intake; UEI Levels; Pregnant Women

\section{ABSTRAK}

Latar Belakang : Gangguan Akibat Kekurangan Yodium (GAKY) merupakan gangguan yang timbul karena kekurangan asupan yodium. Masalah GAKY di Indonesia cukup banyak. Oleh karena itu, pentingnya sosialisasi asupan yodium yang cukup agar dapat mengurangi resiko terjadinya GAKY di masyarakat. Kelompok yang perlu mendapat sosialisasi pentingnya memperhatikan kadar yodium yaitu wanita usia subur dan ibu hamil.

Tujuan : Menganalisis hubungan antara kadar Ekskresi Iodium Urin (EIU) dengan LILA, IMT, status anemia, konsumsi garam dan pola makan subjek.

Metode : Penelitian ini merupakan studi observasional yang dilakukan dengan desain Cross Sectional. Subjek dalam penelitian ini adalah ibu hamil trimester 2 dan trimester 3 yang tinggal di wilayah kerja Puskesmas Mlonggo II dan Puskesmas Pakis Aji, Jepara. Total sampel 88 ibu hamil dengan teknik sampling yang diambil adalah consecutive sampling. Instrumen penelitian ini yaitu kuesioner, wawancara terkait asupan makan maupun asupan garam beryodium (SQ-FFQ) dan botol urine untuk tempat urine subyek sebelum diuji dengan metode Enzym Linked Immunosorben Assay (ELISA). Analisis data dilakukan dengan analisis deskriptif rensponden dengan menyajikan distribusi frekuensi masing-masing variabel. Analisis biavariat yaitu untuk mengetahui besar risiko (odds ratio) paparan terhadap kasus dengan menggunakan table $2 \times 2$.

Hasil : Ibu hamil pada penelitian ini sebanyak 88 subjek. Subjek yang memiliki kadar EIU rendah sebanyak 68,2\%. Selain itu dari total subjek, terdapat 46 subjek yang memiliki status gizi overweight $(52,3 \%)$ dan sebanyak 19 subjek $(21,6 \%)$ mengalami anemia. Dari hasil uji statistik menunjukkan bahwa tidak adanya hubungan antara LILA $(p=0,843)$, status gizi $(p=0,282)$, status anemia $(p=0,561)$, asupan energi $(p=0,360)$; asupan karbohidrat $(p=0,856)$; asupan protein $(p=0,744)$; asupan lemak $(p=0,781)$; asupan serat $(p=0,492)$; asupan vitamin $\mathrm{C}(p=0,401)$; asupan magnesium 
$(p=0,177)$; asupan zat besi $(\mathrm{Fe})(p=0,122)$; asupan zink $(p=0,141)$; asupan mangan $(p=0,286)$ dengan kadar EIU pada ibu hamil.

Simpulan : Tidak terdapat hubungan antara karakteristik, pola konsumsi garam dan pola makan dengan kadar EIU pada ibu hamil.

Kata Kunci : Yodium; Pola Makan; Kadar Eksresi Iodium Urin; Ibu Hamil

\section{PENDAHULUAN}

Gangguan Akibat Kurang Yodium (GAKY) di Indonesia merupakan salah satu masalah kesehatan yang serius bagi masyarakat mengingat dampaknya sangat besar terhadap kesehatan dan kecerdasan yang mempengaruhi kelangsungan hidup serta kualitas sumber daya manusia. ${ }^{1}$ Masalah GAKY di Indonesia disebabkan karena kurangnya cakupan konsumsi garam beryodium yang memenuhi syarat oleh rumah tangga atau masyarakat. Hal tersebut karena pengetahuan masyarakat tentang pentingnya garam beryodium bagi kesehatan dan kecerdasan rendah. ${ }^{2}$

Yodium adalah mikronutrien penting untuk semua kalangan tak terkecuali ibu hamil, hal tersebut karena yodium berguna untuk memproduksi hormon tiroid. Pada masa kehamilan, produksi hormon tiroid ibu meningkat 50\%. Oleh karena itu, wanita hamil lebih rentan terhadap kekurangan yodium daripada populasi umum dan membutuhkan asupan yodium yang optimal selama kehamilan, agar dapat membantu mencegah gejala Gangguan Akibat Kekurangan Yodium (GAKY). WHO/UNICEF/IGN merekomendasikan asupan yodium harian $250 \mu \mathrm{g}$ untuk menjaga kecukupan selama kehamilan. ${ }^{3}$ Menurut Song (2009), kekurangan yodium dapat mengakibatkan keterbelakangan mental, demensia total, dan gangguan saraf pusat yang menyebabkan penurunan IQ. ${ }^{2}$

Terdapat beberapa penyebab terjadinya GAKY, yaitu kondisi geografis yang tidak mengandung yodium atau rendah yodium, rendahnya konsumsi yodium. Makanan yang tinggi yodium merupakan makanan yang juga tinggi protein, seperti ikan laut, udang, kerang, dan ganggang laut. Sebuah penelitian yang dilakukan oleh Patuti, et al. menunjukkan bahwa rendahnya konsumsi sumber protein akan menyebabkan seseorang berpeluang menderita GAKY 30,6 kali lebih besar dibandingkan dengan seseorang yang tidak menderita GAKY. ${ }^{4}$

Ada beberapa upaya pemerintah dalam menanggulangi GAKY yaitu dengan sosialisasi kepada masyarakat tentang pentingnya konsumsi garam beryodium dan dampak yang timbulkan dari penyakit akibat kekurangan yodium. ${ }^{5}$ Pemerintah juga mendukung agar masyarakat meningkatkan asupan makan tinggi yodium terutama pada ikan laut. ${ }^{4}$ Selain itu, GAKY juga disebabkan oleh tingginya asupan makanan yang mengandung zat goitrogenik (ubi kayu, jagung, rebung, ubi jalar, buncis, kol, rebung, sawi, dan selada air), faktor genetik, penggunaan KB hormonal yang berpengaruh pada fungsi tiroid. ${ }^{6}$

Beberapa kelompok rawan GAKY adalah Ibu hamil dan wanita usia subur (WUS). Fungsi tiroid pada trimester pertama akan menentukan kualitas anak yang akan dilahirkan. Hormon tiroid sangat dibutuhkan untuk perkembangan otak, sehingga kekurangan hormon tiroid akan memberikan akibat jangka panjang, contohnya abortus spontan, gangguan tumbuh kembang janin, placental abruption, bayi lahir sebelum waktunya, lahirnya bayi kretin serta terjadi gangguan susunan saraf pusat pada janin yang berdampak pada kecerdasan dan perkembangan social. ${ }^{7}$

Hasil pemeriksaan ekskresi iodium dalam urin (EIU) di Kabupaten Jepara pada tahun 2007 2012 menunjukkan endemis GAKY yaitu Mayong, Batealit dan Pakis Aji. Tingkat konsumsi garam beriodium rumah tangga di Kabupaten Jepara sebesar 79,89\% namun konsumsi garam beriodium cukup (secara kualitatif dengan iodine test) sebesar $60,27 \%$. Jumlah ibu hamil di Kabupaten Jepara sekitar 22.897 orang, maka diperkirakan $9.097 \mathrm{ibu}$ hamil berisiko melahirkan bayi dengan disfungsi neuropsikologi. ${ }^{8}$

Oleh karena itu, mengingat Jepara merupakan daerah pesisir yang berdasarkan kajian bukan daerah endemik GAKY, peneliti akan menganalisis hubungan antara asupan zat gizi, dan pola konsumsi garam beryodium dengan kadar ekskresi iodium urin Ibu hamil trimester 2 dan trimester 3 di wilayah Kabupaten Jepara khususnya Mlonggo dan Pakis Aji.

\section{METODE}

Jenis penelitian ini adalah studi observasional yang dilakukan dengan desain cross sectional. Subjek dalam penelitian ini diambil 
dengan metode consecutive sampling sebanyak 88 ibu hamil dengan kriteria wanita usia subur (WUS), usia kehamilan trimester 2 dan 3, bertempat tinggal di wilayah kerja Puskesmas Mlonggo dan Puskesmas Pakis Aji Kabupaten Jepara. Penelitian dilakukan pada bulan Agustus-September 2020. Penelitian ini bertujuan untuk mengetahui tiga variabel (karakteristik, pola konsumsi garam beryodium, dan pola makan) dengan kadar ekskresi iodium urin.

Pengumpulan data dilakukan dengan pengisian kuesioner, wawancara subjek terkait asupan makan (SQ-FFQ) dan pemeriksaan laboratorium untuk pemeriksaan darah dan urin. Wawancara kuesioner dilakukan untuk mengetahui karakteristik subjek yakni lingkar lengan atas (LILA), indeks massa tubuh (IMT), status anemia serta mengetahui asupan makan subjek, baik zat gizi makro dan zat gizi mikro. Selain itu juga dilakukan pengambilan urin sesaat masing-masing subjek $10 \mathrm{ml}$ dengan menggunakan botol urin yang sudah diberikan. Pengukuran kadar EIU dengan metode Enzym Linked Immunosorben Assay (ELISA).

Hasil penelitian dianalisis menggunakan analisis univariat, yaitu analisis yang digunakan pada satu variabel dengan tujuan untuk mengetahui dan mengidentifikasi distribusi frekuensi dan karakteristik dari masing-masing variabel. Analisis kualitatif untuk mengetahui tingkat pengetahuan subjek mengenai pengetahuan tentang gizi, GAKY dan konsumsi garam beryodium serta konsumsi makanan sehari hari. Analisis biavariat dengan menggunakan uji Chi-square, yaitu untuk mengetahui besar risiko (odds ratio) paparan terhadap kasus dengan menggunakan table $2 \times 2$. Sebelum dilakukan pemeriksaan laboratorium, wawancara dan pemeriksaan fisik, subyek menandatangani informed concent yang telah disetujui ethical clearence nya oleh Komisi Etik Penelitian Kesehatan (KEPK) Fakultas Kedokteran Universitas Diponegoro dengan No. 101/EC/KEPK/FK-UNDIP/VI/2020.

\section{HASIL}

Setelah melakukan penelitian di wilayah Kecamatan Pakis Aji dan Kecamatan Mlonggo didapatkan sampel sebanyak 88 sampel ibu hamil dengan hasil dalam tabel 1 .

Berdasarkan Tabel 1, dapat dilihat bahwa sebagian besar kadar EIU tergolong kurang yakni sebanyak $68,2 \%$ subjek. Sebanyak $77,3 \%$ ibu hamil yang menjadi subjek memiliki ukuran LILA dengan kategori cukup $(\geq 23,5 \mathrm{~cm})$. Di samping itu, status gizi juga menjadi salah satu variabel yang diukur pada penelitian ini. Sebagian dari subjek yakni sebanyak 52,3\% subjek memiliki status gizi overweight. Selain itu, terdapat $78,4 \%$ subjek yang tidak mengalami anemia sedangkan sisanya sebanyak $21,6 \%$ subjek mengalami anemia. Melihat hasil sebaran data asupan makan subjek, masingmasing zat gizi makro mulai tingkat asupan energi $55,7 \%$, karbohidrat $38,60 \%$, dan lemak $38,60 \%$ tergolong cukup. Namun sebanyak $62,50 \%$, tingkat asupan zat gizi protein subjek kurang. Selain zat gizi makro, adapun zat gizi mikro yang dianalisis. Tingkat asupan zat gizi vitamin C sebanyak 56,80\%, zat gizi magnesium sebanyak $54,50 \%$, tingkat asupan zat besi $(\mathrm{Fe})$ sebanyak $93,20 \%$, dan tingkat asupan zink sebanyak 98,90\% tergolong pada asupan yang kurang dari angka kecukupan gizi. Sedangkan sebanyak 93,20\%, asupan zat gizi mangan pada subjek tergolong kurang dari angka kecukupan gizi $(<80 \%)$.

Tabel 2 menunjukkan bahwa tidak adanya keterkaitan antara LILA $(p=0,843)$, status gizi $(p=0,282)$, status anemia $(p=0,561)$ dan asupan energi $(p=0,360)$; asupan karbohidrat $(p=0,856)$; asupan protein $(p=0,744)$; asupan lemak $(p=0,781)$; asupan serat $(p=0,492)$; asupan vitamin $\mathrm{C}(p=$ $0,401)$; asupan magnesium $(p=0,177)$; asupan zat besi $(\mathrm{Fe})(p=0,122)$; asupan zink $(p=0,141)$; asupan mangan $(p=0,286)$ dengan kadar EIU pada ibu hamil di daerah tersebut. Namun jika melihat odd ratio nya, masing-masing faktor risiko LILA $(\mathrm{OR}=1,16)$ artinya subjek dengan ukuran LILA $\geq 23,5 \mathrm{~cm}$ maka akan berisiko mengalami kenaikan kadar EIU 1,16x lebih tinggi. Begitu pula dengan status anemia $(\mathrm{OR}=1,4)$ artinya subjek yang mengalami anemia maka akan berisiko mengalami kekurangan kadar UEI 1,4 x lebih tinggi.

\section{PEMBAHASAN}

Hasil penelitian menunjukkan terdapat $68,2 \%$ ibu hamil yang mengalami kekurangan kadar EIU. Pengukuran kadar EIU menjadi salah satu metode untuk mengukur status yodium karena sekitar $90 \%$ yodium dalam tubuh akan diekskresikan melalui urin sehingga dapat menggambarkan asupan yodium seseorang. ${ }^{10}$ Penyebab utama seseorang memiliki kadar EIU rendah adalah kurangnya asupan yodium baik dari makanan, minuman ataupun penggunaan garam yang kurang beryodium. ${ }^{6}$ Selain mengukur kadar EIU, dilakukan pengukuran status gizi pada ibu hamil. Status gizi menjadi akibat dari konsumsi makanan dan penggunaan zat gizi yang mempengaruhi keadaan tubuh seseorang. ${ }^{1}$ Penilaian status gizi pada ibu hamil secara langsung antara lain memantau penambahan berat badan selama hamil dan mengukur LiLA. ${ }^{12}$ LILA adalah ukuran lingkar lengan atas subjek yang diukur dengan pita ukur dengan kriteria LILA normal $(\geq 23,5)$. 
Tabel 1. Distribusi Frekuensi Kadar EIU, LILA, Status Gizi, Status Anemia dan Asupan Makan Subjek

\begin{tabular}{|c|c|c|}
\hline \multirow{2}{*}{ Variabel } & \multicolumn{2}{|c|}{ Frekuensi } \\
\hline & $\mathbf{n}$ & $\%$ \\
\hline \multicolumn{3}{|c|}{$\begin{array}{l}\text { Kadar Ekskresi Iodium Urin } \\
(\mathrm{EIU})^{9}\end{array}$} \\
\hline Kurang & 60 & 68,2 \\
\hline Cukup & 28 & 31,8 \\
\hline \multicolumn{3}{|l|}{ LILA } \\
\hline Kurang & 20 & 22,7 \\
\hline Cukup & 68 & 77,3 \\
\hline \multicolumn{3}{|l|}{ Status Gizi } \\
\hline Underweight & 15 & 17 \\
\hline Normal & 27 & 30,7 \\
\hline Overweight & 46 & 52,3 \\
\hline \multicolumn{3}{|l|}{ Status Anemia } \\
\hline $\mathrm{Ya}$ & 19 & 21,6 \\
\hline Tidak & 69 & 78,4 \\
\hline \multicolumn{3}{|l|}{ Asupan Energi } \\
\hline Kurang $(<80 \%)$ & 31 & $35,2 \%$ \\
\hline Cukup $(80 \%-110 \%)$ & 49 & $55,7 \%$ \\
\hline Berlebih $(>110 \%)$ & 8 & $9,1 \%$ \\
\hline \multicolumn{3}{|l|}{ Asupan Karbohidrat } \\
\hline Kurang $(<80 \%)$ & 34 & $38,6 \%$ \\
\hline Cukup $(80 \%-110 \%)$ & 34 & $38,6 \%$ \\
\hline Berlebih $(>110 \%)$ & 20 & $22,7 \%$ \\
\hline \multicolumn{3}{|l|}{ Asupan Protein } \\
\hline Kurang $(<80 \%)$ & 55 & $62,5 \%$ \\
\hline Cukup (80\%-110\%) & 23 & $26,1 \%$ \\
\hline Berlebih $(>110 \%)$ & 10 & $11,4 \%$ \\
\hline \multicolumn{3}{|l|}{ Asupan Lemak } \\
\hline Kurang $(<80 \%)$ & 30 & $34,1 \%$ \\
\hline Cukup (80\%-110\%) & 34 & $38,6 \%$ \\
\hline Berlebih $(>110 \%)$ & 24 & $27,3 \%$ \\
\hline \multicolumn{3}{|l|}{ Asupan Serat } \\
\hline Kurang $(<80 \%)$ & 87 & $98,90 \%$ \\
\hline Cukup (80\%-110\%) & 0 & $0,00 \%$ \\
\hline Berlebih $(>110 \%)$ & 1 & $1,10 \%$ \\
\hline \multicolumn{3}{|l|}{ Asupan Vitamin C } \\
\hline Kurang $(<80 \%)$ & 50 & $56,80 \%$ \\
\hline Cukup (80\%-110\%) & 18 & $20,50 \%$ \\
\hline Berlebih $(>110 \%)$ & 20 & $22,70 \%$ \\
\hline \multicolumn{3}{|l|}{ Asupan Magnesium (Mg) } \\
\hline Kurang $(<80 \%)$ & 48 & $54,50 \%$ \\
\hline Cukup (80\%-110\%) & 27 & $30,70 \%$ \\
\hline Berlebih $(>110 \%)$ & 13 & $14,80 \%$ \\
\hline \multicolumn{3}{|l|}{ Asupan Besi $(\mathrm{Fe})$} \\
\hline Kurang $(<80 \%)$ & 82 & $93,20 \%$ \\
\hline Cukup (80\%-110\%) & 5 & $5,70 \%$ \\
\hline Berlebih $(>110 \%)$ & 1 & $1,10 \%$ \\
\hline \multicolumn{3}{|l|}{ Asupan Zink (Zn) } \\
\hline Kurang $(<80 \%)$ & 87 & $98,90 \%$ \\
\hline Cukup (80\%-110\%) & 1 & $1,10 \%$ \\
\hline Berlebih $(>110 \%)$ & 0 & 0 \\
\hline \multicolumn{3}{|l|}{ Asupan Mangan (Mn) } \\
\hline Kurang $(<80 \%)$ & 1 & $1,10 \%$ \\
\hline Cukup (80\%-110\%) & 5 & $5,70 \%$ \\
\hline Berlebih $(>110 \%)$ & 82 & $93,20 \%$ \\
\hline
\end{tabular}


Tabel 2. Hubungan LILA, Status Gizi, dan Status Anemia dengan Kadar EIU

\begin{tabular}{|c|c|c|c|c|c|c|}
\hline \multirow{3}{*}{ Variabel } & \multicolumn{4}{|c|}{ Kadar Ekskresi Iodium Urin } & \multirow{3}{*}{$p$} & \multirow{3}{*}{ OR } \\
\hline & \multicolumn{2}{|c|}{ Kurang } & \multicolumn{2}{|c|}{ Cukup } & & \\
\hline & $\mathrm{n}$ & $\%$ & $\mathrm{n}$ & $\%$ & & \\
\hline \multicolumn{7}{|l|}{ LILA } \\
\hline Kurang & 14 & 15,91 & 6 & 6,82 & \multirow[t]{2}{*}{0,843} & \multirow[t]{2}{*}{1,116} \\
\hline Cukup & 46 & 52,27 & 22 & 25,00 & & \\
\hline \multicolumn{7}{|l|}{ IMT } \\
\hline Underweight & 12 & 13,64 & 3 & 3,41 & \multirow{3}{*}{0,282} & \\
\hline Normal & 20 & 22,73 & 7 & 7,95 & & \\
\hline Overweight & 28 & 31,82 & 18 & 20,45 & & \\
\hline \multicolumn{7}{|l|}{ Status Anemia } \\
\hline Ya & 14 & 15,91 & 5 & 5,68 & \multirow[t]{2}{*}{0,561} & \multirow[t]{2}{*}{1,4} \\
\hline Tidak & 46 & 52,27 & 23 & 26,14 & & \\
\hline \multicolumn{7}{|l|}{ Asupan Energi } \\
\hline Kurang $(<80 \%)$ & 20 & 23 & 11 & 13 & \multirow{3}{*}{0,360} & \\
\hline Cukup (80\%-110\%) & 36 & 41 & 13 & 15 & & \\
\hline Berlebih $(>110 \%)$ & 4 & 5 & 4 & 5 & & \\
\hline \multicolumn{7}{|l|}{ Asupan Karbohidrat } \\
\hline Kurang $(<80 \%)$ & 24 & 27 & 10 & 11 & \multirow{3}{*}{0,856} & \\
\hline Cukup (80\%-110\%) & 22 & 25 & 12 & 14 & & \\
\hline Berlebih $(>110 \%)$ & 14 & 16 & 6 & 7 & & \\
\hline \multicolumn{7}{|l|}{ Asupan Protein } \\
\hline Kurang $(<80 \%)$ & 39 & 44 & 16 & 18 & \multirow{3}{*}{0,744} & \\
\hline Cukup (80\%-110\%) & 15 & 17 & 8 & 9 & & \\
\hline Berlebih (>110\%) & 6 & 7 & 4 & 5 & & \\
\hline \multicolumn{7}{|l|}{ Asupan Lemak } \\
\hline Kurang $(<80 \%)$ & 19 & 22 & 11 & 13 & 0781 & \\
\hline Cukup (80\%-110\%) & 24 & 27 & 10 & 11 & $0, / 81$ & \\
\hline Berlebih $(>110 \%)$ & 17 & 19 & 7 & 8 & & \\
\hline Asupan Serat & & & & & & \\
\hline Kurang $(<80 \%)$ & 59 & 67 & 28 & 32 & & \\
\hline Cukup (80\%-110\%) & 0 & 0 & 0 & 0 & 0,492 & \\
\hline Berlebih (>110\%) & 1 & 1 & 0 & 0 & & \\
\hline Asupan Vitamin C & & & & & & \\
\hline Kurang $(<80 \%)$ & 35 & 40 & 15 & 17 & & \\
\hline Cukup (80\%-110\%) & 10 & 11 & 8 & 9 & 0,401 & \\
\hline Berlebih $(>110 \%)$ & 15 & 17 & 5 & 6 & & \\
\hline Asupan Magnesium (N & & & & & & \\
\hline Kurang $(<80 \%)$ & 35 & 40 & 13 & 15 & 177 & \\
\hline Cukup (80\%-110\%) & 19 & 22 & 8 & 9 & $0,1 / 7$ & \\
\hline Berlebih $(>110 \%)$ & 6 & 7 & 7 & 8 & & \\
\hline Asupan Besi (Fe) & & & & & & \\
\hline Kurang $(<80 \%)$ & 58 & 66 & 24 & 27 & & \\
\hline Cukup (80\%-110\%) & 2 & 2 & 3 & 3 & 0,122 & \\
\hline Berlebih $(>110 \%)$ & 0 & 0 & 1 & 1 & & \\
\hline Asupan Zink (Zn) & & & & & & \\
\hline Kurang $(<80 \%)$ & 60 & 68 & 27 & 31 & & \\
\hline Cukup (80\%-110\%) & 0 & 0 & 1 & 1 & 0,141 & \\
\hline Berlebih (>110\%) & 0 & 0 & 0 & 0 & & \\
\hline
\end{tabular}


(Lanjutan) Tabel 2. Hubungan LILA, Status Gizi, dan Status Anemia dengan Kadar EIU

\begin{tabular}{|c|c|c|c|c|c|c|}
\hline \multirow{3}{*}{ Variabel } & \multicolumn{4}{|c|}{ Kadar Ekskresi Iodium Urin } & \multirow{3}{*}{$p$} & \multirow{3}{*}{ OR } \\
\hline & \multicolumn{2}{|c|}{ Kurang } & \multicolumn{2}{|c|}{ Cukup } & & \\
\hline & $\mathrm{n}$ & $\%$ & $\mathrm{n}$ & $\%$ & & \\
\hline \multicolumn{7}{|l|}{ Asupan Mangan (Mn) } \\
\hline Kurang $(<80 \%)$ & 0 & 0 & 1 & 1 & \multirow{3}{*}{0,286} & \\
\hline Cukup (80\%-110\%) & 3 & 3 & 2 & 2 & & \\
\hline Berlebih $(>110 \%)$ & 57 & 65 & 25 & 28 & & \\
\hline
\end{tabular}

Status gizi ibu hamil yang diukur melalui LiLA menggambarkan cadangan zat gizi dan kondisi status gizi ibu di masa pra hamil sedangkan kadar EIU merupakan gambaran asupan yodium harian. ${ }^{13}$ Hal ini sangat bertolak belakang karna kadar EIU tidak bisa menggambarkan asupan yodium terdahulu. Oleh karena itu, berdasarkan hasil uji statistic Chi-Square, tidak ada hubungan yang bermakna antara ukuran LiLA dengan kadar EIU subjek $(p=0,843)$. Hal ini bisa dilihat pada tabel 2 bahwa subjek yang memiliki ukuran LiLA $\geq 23,5$ dan memiliki kadar EIU yang kurang sebanyak $52,27 \%$. Maka dari itu, ukuran LiLA yang kurang tidak dapat dihubungkan dengan kadar EIU yang kurang. Selain LiLA, indeks massa tubuh juga digunakan untuk mengukur status gizi pada penelitian ini. Berdasarkan uji statsitik Chi_Square didapatkan bahwa tidak terdapat hubungan antara indeks massa tubuh dengan kadar EIU. Hasil ini sesuai dengan penelitian lain bahwa tidak terdapat hubungan antara IMT dengan kadar EIU. ${ }^{14} \mathrm{Hal}$ ini dikarenakan kadar EIU hanya menunjukkan status GAKI saat ini. Padahal indeks masa tubuh merupakan dampak jangka panjang dari keseimbangan energi. Hal ini tidak sesuai dengan kadar EIU yang hanya dapat menggambarkan keadaan saat ini. ${ }^{14}$

Status gizi merupakan gambaran jangka panjang dari keseimbangan asupan zat gizi makro dan zat gizi mikro dengan aktifitas yang dilakukan. Hasil dari penelitian ini menunjukkan bahwa LILA subjek sebanyak $77,30 \%$ termasuk pada kategori baik $(>23,5 \mathrm{~cm})$. Hal tersebut dapat terlihat dari tingkat asupan masing-masing zat gizi, baik zat gizi makro (karbohidrat, protein, lemak, serat) maupun zat gizi mikro (vitamin $\mathrm{C}$, magnesium, zat besi/Fe, mangan, zink). Dapat terlihat pada tabel 1, tingkat asupan 3 zat gizi makro dari 5 termasuk dalam kategori cukup (energi 55,7\%; karbohidrat 38,6\%; lemak $38,6 \%$ ). Sedangkan untuk asupan protein sebanyak $62,50 \%$ subjek dan serat sebanyak $98,90 \%$ subjek termasuk dalam kategori kurang. Penggolongan asupan subjek mengacu pada angka kecukupan gizi ibu hamil (AKG), asupan dalam kategori kurang jika $<80 \%$, apabila dikatakan kategori cukup jika asupan subjek 80\% - 110\%, sedangkan jika asupan subjek $>110 \%$ dari AKG maka termasuk kategori berlebih. ${ }^{15}$ Selain zat gizi makro, tabel 1 juga menunjukkan bahwa vitamin $\mathrm{C}$ sebanyak 56,80\% subjek, magnesium sebanyak $54,50 \%$ subjek, zat besi/Fe sebanyak 93,20\% subjek, zink sebanyak 98,90\% subjek termasuk dalam kategori kurang dari AKG. Sedangkan asupan zat gizi mangan sebanyak $93,20 \%$ subjek termasuk kategori berlebih.

Hasil uji lanjutan statistik antara pola makan/asupan makan subjek dengan kadar EIU menunjukkan bahwa tidak ada hubungan yang bermakna antara keduanya, baik energi $(p=0,360)$; karbohidrat $(p=0,856)$; protein $(p=0,744)$; lemak $(p=0,781)$; serat $(p=0,492)$; vitamin $\mathrm{C}(p=0,401)$; magnesium $(p=0,177)$; zat besi/Fe $(p=0,122)$; zink $(p=0,141)$; dan mangan $(p=0,286)$. Hasil penelitian ini tidak sejalan dengan salah satu hasil penelitian di China, dimana hasil mereka menunjukkan bahwa adanya hubungan antara asupan ibu hamil dengan kadar EIU. Hasil membuktikan bahwa rendahnya asupan ibu hamil terutama asupan iodium akan menyebabkan kadar EIU ibu hamil rendah dan akan mengakibatkan terganggunya stimulasi hormon tiroid. Kecukupan iodium tubuh dinilai dari iodium yang masuk lewat makanan dan minuman, sebab tubuh tidak dapat mensintesis iodium. Oleh karena yang dibutuhkan amat sedikit (dalam ukuran mikro) dan dalam makanan sukar diperiksa, maka indikator kecukupan iodium diperiksa berdasarkan ekskresi iodium dalam urin (EIU). Indikator lain seperti gondok merupakan reaksi tubuh atas kurang hormon tiroid (akibat kurang suplai iodium) adalah ukuran tak langsung dari defisiensi iodium. ${ }^{16}$ Kecukupan iodium berdasarkan ekskresi iodium dalam urin (EIU) sesuai rekomendasi WHO, UNICEF, ICCIDD 
adalah sebagai berikut: defisiensi berat nilai EIU < $20 \mu \mathrm{g} / \mathrm{l}$, defisiensi sedang nilai EIU 20 - $49 \mu \mathrm{g} / \mathrm{l}$, defisiensi ringan nilai EIU 50 - $99 \mu \mathrm{g} / \mathrm{l}$, cukup 100 $199 \mu \mathrm{g} / \mathrm{l}$, lebih dari cukup $200-299 \mu \mathrm{g} / \mathrm{l}$ dan excess jika nilai EIU $>300 \mu \mathrm{g} / \mathrm{l}$. Perbedaan hasil kemungkinan dikarenakan adanya faktor lain yang mempengaruhi kondisi masing-masing subjek. ${ }^{17}$

Di samping itu, status anemia subjek juga diukur dalam penelitian ini. Hampir sebagian besar subjek tidak mengalami anemia. Dari hasil uji statistik didapatkan bahwa tidak ada hubungan yang bermakna antara status anemia dengan kadar EIU $(p=0,561)$ Dilihat dari tabel 2, sebanyak 52,27\% subjek yang non-anemia mengalami kekurangan kadar EIU. Hal ini sejalan dengan penelitian yang dilakukan oleh Iqbal dkk, dimana hasil penelitian mereka menunjukkan bahwa zat besi tidak berhubungan dengan kadar EIU. Namun hasil sebuah penelitian di Sri Lanka menunjukkan adanya penurunan kadar iodium pada ibu hamil seiring dengan perkembangan kehamilan. ${ }^{18}$

Hal tersebut dikarenakan zat besi merupakan mikronutrien bagi enzim deiodinase dan berperan dalam aktivasi enzim TPO (Tiroid Peroxidase), sedangkan iodium merupakan bahan baku utama dalam produksi hormon tiroid. ${ }^{19}$ Pada penelitian tersebut, pengukuran tidak menggunakan kadar EIU sebagai indikator status gaky melainkan menggunakan indikator volume kelenjar tiroid. Kadar EIU hanya bisa digunakan untuk mengetahui asupan yodium harian sedangkan indikator volume kelenjar tiroid merupakan indikator klinis yang menunjukkan proses lebih lama. ${ }^{20}$

\section{SIMPULAN}

Tidak terdapat hubungan antara faktor risiko dan pola konsumsi dengan kadar EIU pada ibu hamil. Hal tersebut dikarenakan beberapa hal yang mempengaruhi. Oleh karena itu perlu dilakukan penelitian lebih lanjut dengan menambah variabel lain agar hasil penelitian lebih menggambarkan hubungannya dengan kadar EIU.

\section{UCAPAN TERIMAKASIH}

Ucapan terimakasih disampaikan kepada subyek penelitian yang telah bersedia menjadi informan dalam penelitian ini, Dinas Kesehatan Kabupaten Jepara, Puskesmas Mlonggo II dan Puskesmas Pakis Aji dan berbagai pihak yang telah membantu dilakukannya studi ini. Penelitian ini didanai oleh Riset Pengembangan dan Penerapan (RPP) sumber dana selain APBN Fakultas Kedokteran Universitas Diponegoro Tahun Anggaran 2020.

\section{DAFTAR PUSTAKA}

1. World Health Organization, Unicef, ICCID. Assessment of the iodine deficiency disorders and monitoring their elimination. 3rd Editio. WHO. Switzerland; 2007. p 1107.

2. Patuti N, Sudargo T, Wachid DN. Faktorfaktor yang berhubungan dengan kejadian GAKY pada anak sekolah dasar di pinggiran pantai Kota Palu Provinsi Sulawesi Tengah. J Gizi Klin Indones. 2010;7(1):17-26.

3. Kusrini I, Farebrother J, Kristanto D. Adequately iodized salt is an important strategy to prevent iodine insufficiency in pregnant women living in central java, Indonesia. PLOS ONE. 2020;15(11):1-13.

4. Izati IM, Mahmudiono T. Pola konsumsi makanan sumber yodium dan goitrogenik dengan gaky pada anak usia sekolah di ponorogo iodine and goitrogenic intake among school children in Ponorogo. Amerta Nutrition. 2017;1(2): 88-97.

5. Kusrini I, Mulyantoro DK, Sukandar PB, Budiman B. Hipotiroidisme pada ibu hamil di daerah replete dan non-replete gondok di Kabupaten Magelang. J Kesehat Reproduksi. 2016; 7(1): 49-59.

6. Alfitri S, Widodo U, Sudargo T. Faktorfaktor pada kejadian GAKY ibu hamil di Tabunganen, Barito Kuala, Kalimantan Selatan. J Gizi dan Diet Indones. 2013; 1(1): 7-14.

7. Agrawal K, Paudel BH, Singh PN, Pokhrel HP, Majhi S. Urinary iodine excretion in pregnancy: a pilot study in the region of Nepal. J Clin Diagnostic Res. 2013; 7(7): 1319-21.

8. Zulaekah S. Hubungan tingkat konsumsi zat gizi dengan status yodium pada wanita usia subur di daerah endemik Gaki. J Public Health. 2010; 3(1): 66-77.

9. Kementrian Kesehatan Republik Indonesia. Hasil Utama Riskesdas 2018. Jakarta: Kemenkes RI. 2018. p 18-9.

10. Mutalazimah M, Mulyono B, Murti B, Azwar S. Asupan Yodium, ekskresi yodium urine, dan goiter pada wanita usia subur di daerah endemis defisiensi yodium. Kesmas Natl Public Heal J. 2013; 8(3):139.

11. Pujiastuti N. Korelasi antara status gizi ibu menyusui dengan kecukupan ASI di posyandu Desa Karang Kedawang Kecamatan Sooko Kabupaten Mojokerto. J Keperawatan. 2010; 1(2): 126-37.

12. Marlapan S, Wantouw B, Sambeka J. 
Hubungan status gizi dengan kejadian anemia pada ibu hamil di wilayah kerja Puskesmas Tuminting Kec. Tuminting Kota Manado. J Keperawatan UNSRAT. 2013; 1(1): 106817.

13. Purwaningtyas ML, Prameswari GN. Faktor kejadian anemia pada ibu hamil. J Public Heal Res adn Dev. 2017;1(3):43-54.

14. Noor Z, Vinenza ER, Rahmatina I. Hubungan kadar yodium urin dengan kejadian anemia dan tumbuh kembang remaja di daerah endemik GAKI Yogyakarta. Mutiara Med. 2012; 12(2): 79-87.

15. Kemenkes RI. Angka Kecukupan Gizi (AKG). Jakarta: Kementerian Kesehatan RI. 2013. p 5-10.

16. Wei Z, Wang W, Zhang J, Zhang X, Jin L, $\mathrm{Yu} \mathrm{X}$. Urinary iodine level and its determinants in pregnant women of Shanghai, China. Br J Nutr. 2015; 113(9): 1427-32.

17. Harika R, Faber M, Samuel F, Kimiywe J, Mulugeta A, Eilander A. Micronutrient status and dietary intake of iron, vitamin a, iodine, folate, and zinc in women of reproductive age and pregnant women in Ethiopia, Kenya, Nigeria, and South Africa: A systematic review of data from 2005 to 2015 . Nutrients. 2017; 9(10): 1-23.

18. Li S, Gao X, Wei Y, Zhu G, Yang C. The relationship between iron deficiency and thyroid function in Chinese women during early pregnancy. J Nutr Sci Vitaminol (Tokyo). 2016; 62(6): 397-401.

19. Iqbal S, Rust P, Weitensfelder L, Ali I, Kundi $\mathrm{M}$, Moshammer $\mathrm{H}$, et al. Iron and iodine status in pregnant women from a developing country and its relation to pregnancy outcomes. Int J Environ Res Public Health. 2019; 16(22): 1-13.

20. Samsudin M, Rahmawati Y, Kusrini I. Kombinasi indikator status iodium pada anak usia sekolah untuk menilai keseriusan gangguan akibat kekurangan iodium. Jurnal Penelitian Gizi dan Makanan. 2012; 35(2): 99-109. 